\title{
Why do occupations dominated by women pay less? How 'female-typical' work tasks and working- time arrangements affect the gender wage gap among higher education graduates
}

Work, employment and society 2016, Vol. 30(5) 802-820 (C) The Author(s) 2016

Reprints and permissions: sagepub.co.uk/journalsPermissions.nav DOI: 10.1 I77/09500I70I5624402 wes.sagepub.com @SAGE

\section{Kathrin Leuze}

Leibniz Universität Hannover, Germany

\section{Susanne Strauß}

University of Konstanz, Germany

\begin{abstract}
Even though women today constitute the majority of higher education graduates, they still earn considerably less than their male counterparts. Previous research demonstrates that occupational sex segregation is important for understanding the gender wage gap, since occupations dominated by women pay less; yet less is known about why this is the case. This article explores two possible mechanisms: the devaluation of 'female-typical' work tasks and working-time arrangements. Hypotheses are tested by applying OLS regression and Blinder-Oaxaca decomposition analyses to the log hourly wages of a representative sample of German higher education graduates from 200I. Results confirm that occupational overtime increases and occupational part-time work decreases wages, indicating that occupations dominated by women pay less due to their 'femaletypical' working-time arrangements. However, inconsistent with the devaluation thesis, tasks like teaching/educating increase wages for women, too, which speaks against a general lower value of 'female-typical' tasks, at least among the highly qualified.
\end{abstract}

\section{Keywords}

gender wage gap, Germany, higher education, occupational sex segregation, working time, work tasks

\section{Corresponding author:}

Kathrin Leuze, Department of Sociology, Leibniz Universität Hannover, Schneiderberg 50, D - 30187

Hannover, Germany.

Email: k.leuze@ish.uni-hannover.de 


\section{Introduction}

Although women's participation in higher education and their labour market involvement have dramatically increased over recent decades, a variety of labour market inequalities between men and women remain. One important and consequential inequality concerns the gender wage gap (i.e. the fact that women earn considerably less than their male colleagues). In many European countries, the unadjusted gender wage gap ${ }^{1}$ is most evident among highly qualified men and women (OECD, 2013: 119) and already occurs early after graduation (Braakmann, 2013; Triventi, 2013). According to Triventi (2013: 569-70), the unadjusted gender wage gap among higher education graduates is particularly pronounced in Germany (30\%) and Austria (32\%) when compared to the United Kingdom and Belgium (both 15\%). This is surprising given that, today, more women than men obtain tertiary degrees in most European countries, including Germany (OECD, 2013: 40).

When analysing the gender wage gap among the highly qualified, the horizontal sex segregation by academic subjects (e.g. Braakmann, 2013; Leuze and Strauß, 2009; Ochsenfeld, 2014) and by occupations (e.g. Grönlund and Magnusson, 2013; Leuze and Strauß, 2014; Triventi, 2013) are identified as important explanations for both Germany and other European countries. To this end, many studies include the proportion of women per subject or occupation as an explanatory variable in their wage equation and show that a higher share of women leads to lower wages. Yet it is far from clear why this is the case (Grönlund and Magnusson, 2013). Possible explanations can be differentiated into two broad strands. The first strand uses the sorting processes of men and women into different subject types as explanatory points of reference (e.g. Braakmann, 2013; Ochsenfeld, 2014), while the second strand focuses on occupations and mechanisms taking place within the labour market (e.g. Grönlund and Magnusson, 2013; Triventi, 2013).

Since previous studies have shown that female-dominated occupations are associated with higher wage penalties than female-dominated subjects (Leuze and Strauß, 2009, 2014), the central research question of this article holds: Why do occupations dominated by women pay less and how does this contribute to our understanding of the gender wage gap among the highly qualified? It contributes to the existing literature by exploring two potential mechanisms which might explain the lower pay for 'female' occupations. On the one hand, it examines the possible devaluation (England, 1992) of 'female-typical' work tasks, since occupations with a high share of women often also involve performing specific tasks that are related to reproductive and care work, which are mainly provided by women in the private sphere and therefore paid less (Bolton and Muzio, 2008; McGrath and DeFilippis, 2009). On the other hand, it investigates the effects of 'femaletypical' working-time arrangements, since changes in the occupational sex composition come along with distinct working-time differences between typical female and male occupations, such as part-time work (Hakim, 1996) or overtime (Cha and Weeden, 2014). Drawing on Acker's (1990) theory of gendered organizations, it is argued that occupations with 'female' working-time arrangements do not correspond to the 'male ideal' of working-time norms and are therefore paid less.

The exclusive focus on higher education graduates in this regard is advantageous because it allows the examination of a group of respondents who are more homogeneous in terms of human capital, duration of labour market integration, phase of family 
formation and who hold predominant stereotypes about 'male' or 'female' activities in certain occupations. Germany constitutes an interesting empirical example in this regard due to its persistently high gender wage gap and its comparatively high levels of sex segregation, even among the highly qualified.

\section{Why should occupations dominated by women pay less? Theoretical considerations}

Many factors contribute to our understanding of the gender wage gap, and the complex relationships between these factors have been analysed in a great number of studies. Most explanations acknowledge the fact that women still bear the main responsibility for housework, childcare and eldercare (Hook, 2010). Gender differences in experience and tenure are (still) marked due to parental leave and subsequent part-time work among mothers and these differences contribute to the gender wage gap (Budig and England, 2001). This is particularly the case in Germany (Gangl and Ziefle, 2009), where the 'modified male breadwinner model' (i.e. a full-time working husband and a wife working at most part-time) is still the dominant way couples participate in the labour market (Trappe et al., 2015). This model is sustained by the interrelation between conservative gender norms regarding the employment of mothers, rather generous parental leave policies and comparatively low levels of public child care, especially for children younger than three years old (Budig et al., 2012), as well as a taxation system based on the unit of the married couple (Dingeldey, 2000). Moreover, wage negotiations used to be based on trade unions' fight for 'family wages', which are paid to (mainly male) core workers and are meant to support the entire family (Gottschall and Schröder, 2013).

All of these explanations are well suited for understanding the gender wage gap among prime age workers in Germany. However, they should be less relevant for higher education graduates at the beginning of their careers. Therefore, the main theoretical argument used in the following is based on the fact that highly qualified men and women continue to specialize in different subjects and subsequently work in different types of occupations.

\section{The selection of men and women into gender-typical subjects and occupations}

The gender-typed sorting processes into subjects and occupations can be explained by rational choice and by socialization theories. According to rational choice theories, women anticipate a more discontinuous work biography compared to men; consequently, they invest less in human capital and tend to rely on general rather than specific skills (Becker, 1962, 1985), prefer occupations with high starting wages and lower wage losses after employment interruptions (Polachek, 1981), as well as with less hazardous and more family-friendly working conditions (Filer, 1985). In contrast, cultural explanations point out the importance of socially shared stereotypes about male and female traits and skills (Charles and Bradley, 2009), which are internalized during childhood and reproduced by everyday interactions between (adult) women and men (Ridgeway, 1997). 
As a consequence of both rational choice and socialization processes, men and women tend to 'choose' gender-typical subjects and occupations (Charles and Bradley, 2009; Helbig and Leuze, 2012). However, regarding the validity of sorting arguments for explaining why occupations dominated by women pay less, empirical evidence is rather mixed. While some studies indicate that women earn less than men because they more often work in occupations requiring less specialized human capital (e.g. Perales, 2013; Tam, 2000), others do not find such a relationship (e.g. England et al., 2000; TomaskovicDevey and Skaggs, 2002), especially if they focus exclusively on the highly qualified (Grönlund and Magnusson, 2013; Leuze and Strauß, 2009; Ochsenfeld, 2014). In addition, the earning profiles of male- and female-dominated occupations do not differ as predicted by human capital theory (England et al., 1988) and the compensating differentials framework (Busch, 2013; Kilbourne et al., 1994).

Most importantly, even after controlling for other explanatory variables on the subject and/or occupational level, many studies still find a negative effect of sex segregation on wages (e.g. England and Li, 2006; England et al., 2000; Grönlund and Magnusson, 2013; Perales, 2013). In addition, sorting-based approaches do not offer an explicit account of why subjects or occupations dominated by women pay less, apart from assuming a lower demand for these fields (Ochsenfeld, 2014). However, it remains unclear whether this lower demand is the result of 'pure' market processes or, as will be discussed later, whether it is the result of other mechanisms, such as employer discrimination or cultural devaluation.

\section{The lower value of 'female-typical' work tasks}

The central idea behind 'devaluation theory' is that women are valued less than men in the culture of western industrialized countries, which is why all things associated with women - including subjects and occupations dominated by women - are valued less in society (England and Li, 2006: 658). As a consequence, 'female-typical' occupations pay lower wages. Possible explanations for these lower pay levels are employer discrimination against women as a result of personal preferences, selective altruism or collusion, employers' systematic cognitive errors when assessing the contribution of 'female' occupations to an organization's profit, or framing effects, since the present pay is used to assess the appropriateness of future pay (England, 1992: 121-22). Moreover, and particularly important for Germany, occupations dominated by women are sheltered less by wage setting institutions, such as trade unions or professional bodies. As a consequence, men benefit more strongly from the political assertion of the 'value' of their 'skill' or 'labour' than women, which results in higher wages for occupations dominated by men (Ziegler, 2005).

So far, many empirical studies support the 'devaluation thesis' (e.g. England, 1992; England et al., 2000, 2002; Perales, 2013). ${ }^{2}$ However, in the literature the issue remains unresolved whether 'female-typical' occupations are valued less simply due to their higher share of women or because of particular tasks performed in these occupations. It has been argued that cultural gender role beliefs involve the idea that reproductive and care work, which is mainly provided by women in the private sphere on the basis of affection, but not for pay, is considered less valuable than paid work (Bolton and Muzio, 
2008; McGrath and DeFilippis, 2009). Such a perspective assumes that the performance of 'female-typical' work tasks, such as caring, nurturing or providing services, rather than the number of women working in an occupation, is the main reason why 'femaletypical' occupations are valued less and therefore paid less (Busch, 2013; Liebeskind, 2004). In Germany, collective bargaining processes support this perspective, since work tasks performed in 'female-typical' occupations are not rewarded monetarily to the same extent as 'male-typical' work tasks (Ziegler, 2005).

However, the research on the relationship between 'female-typical' activities and the gender wage gap is inconclusive. Some studies find that tasks typically associated with women, such as personal and caring services (England et al., 2002; Kilbourne et al., 1994) or cleaning, desk work and sales (Liebeskind, 2004) lead to lower wages. In contrast, other 'female-typical' activities, such as preparing meals, nursing, healing, or teaching were not found to reduce wages (Liebeskind, 2004) or to lead to monetary disadvantages for men only (Busch, 2013). In sum, although both dimensions - the sex composition of occupations and 'female-typical' tasks - are important aspects of why 'female-typical' occupations might be valued less in society, it is necessary to systematically differentiate their influence on wages empirically. Therefore, our first hypothesis (H1) holds that occupations dominated by women pay less because they require performance of 'female-typical' tasks more often and performance of 'male-typical tasks' less often, both of which contribute to the gender wage gap among the highly qualified. Since there is evidence that the societal images of 'male' or 'female' tasks differ between educational groups (Buchmann and Kriesi, 2012), it is advantageous to focus the empirical analysis on higher education graduates in order to deal with more homogeneous images of 'maleness' and 'femaleness' of occupational activities.

\section{The lower value of 'female-typical' working-time arrangements}

Occupations dominated by women not only involve 'female-typical' work tasks, but also working-time arrangements stereotypically associated with women. It is a wellestablished finding that women with children often reduce their working hours or even exit the labour force (Steiber and Haas, 2012). However, it is important to note that women's working-time arrangements are not (only) the result of individual choices and preferences (Hakim, 1996), but are (also) linked to particular opportunity structures resulting from welfare state institutions (Nieuwenhuis et al., 2012; Stadelmann-Steffen, 2008) or occupations.

The latter idea is supported by Acker's (1990) theory of gendered organizations, according to which the behaviour and perspectives of male workers, including their working-time arrangements, are assumed to represent the norm for organizational structures and processes (Acker, 1990: 142). Therefore, the organizational logic considers workers who entirely commit themselves to their paid employment (e.g. by working full-time and overtime, by always being present at the workplace and also by being willing to travel a lot) as 'naturally' more suited to taking on responsibility and authority (Acker, 1990: 149). As a consequence, they fill higher-level hierarchical positions and are paid more. The lower value of 'women's jobs' is explained by women's responsibility for childrearing and domestic chores, which is why they are more likely to work part-time and from home. 
Thus, they do not correspond to the 'male' norms of the organizational structure, which is taken as a justification for paying them lower wages (Acker, 1990).

The logic of gendered organizations can also be applied to occupations. Occupations that are considered 'male' in terms of working-time norms (e.g. overtime, night work) are assumed to represent responsibility and authority and are thus associated with more 'status worthiness'. In contrast, occupations that are considered 'female' in terms of working-time norms (part-time work, telework) are seen as less valuable because they can be more easily combined with family responsibilities and household duties and are thus considered less productive. As a consequence, occupations with 'male-typical' working-time arrangements are paid more because they support the societal image of 'hegemonic masculinity' (Connell, 1987) and are therefore socially more valuable than occupations with 'female-typical' working-time arrangements.

There is some empirical support for the theoretical idea that working-time arrangements are closely linked to occupations dominated by men or women. In male-dominated occupations, part-time employment is seen as hindering careers, while overtime, constant availability and travelling constitute the norm (Crompton and Lyonette, 2011; Herman and Lewis, 2012). Moreover, occupations with a high share of workers reporting overtime pay higher wages (Busch, 2013) and also explain changes in the gender wage gap for the US (Cha and Weeden, 2014). These findings suggest that working-time arrangements are not merely the outcome of individual preferences, but are also the result of 'female' and 'male' working-time norms prevalent at the level of occupations. However, this hypothesis has not been tested systematically by taking into account a large variety of working-time arrangements, such as part-time work, overtime, night work or telework. Therefore, for $\mathrm{H} 2$, it is expected that occupations dominated by women pay less because they are associated more often with 'female-typical' working-time arrangements and less often with 'male-typical' working-time arrangements, both of which contribute to the gender wage gap among the highly qualified.

\section{Data, variables and methods}

The hypotheses were tested empirically by using data from a representative survey of higher education graduates who received their degree from a German higher education institution in 2001 (HIS-Absolventenpanel 2001; Schramm and Beck, 2010). The survey includes detailed questions on the qualification(s) obtained in higher education and the transition to the labour market at intervals of one (2001/2002) and five (2005/2006) years after graduation (see Schramm and Beck, 2010). ${ }^{3}$ Based on this dataset, the dependent variable was derived, namely the natural log of gross hourly wages, ${ }^{4}$ of graduates five years after graduation. ${ }^{5}$ It is advantageous to model logged wages since they are less sensitive to outliers, more closely resemble a Gaussian distribution and can be easily interpreted as per cent change in mean wages if the independent variable is increased by one unit (Petersen, 1989).

These individual-level survey data were combined with information on the level of occupations derived from two different sources. The share of women in a certain occupation was calculated as the weighted mean of women in each occupational category listed in the three-digit occupational classification of the German Federal Statistical Agency 
1992 (Klassifikation der Berufe, 1992) using data from the German Microcensus 2005 (Lechert and Schimpl-Neimanns, 2007). Occupations with less than 30 per cent women are, for example, engineers for surveying and mapping, machine engineers or computer scientists, while occupations with more than 70 per cent women are, for example, primary school teachers, remedial teachers or librarians.

Based on the same data source, occupational working-time arrangements were measured by computing the weighted mean of four indicators for each occupational category: the share of respondents who report working (1) part-time (mean: 17\%), (2) partially from home (telework) (mean: 35\%), (3) overtime (mean: 16\%) and (4) at night (mean: $25 \%$ ). Occupations with a high share of part-time work and telework are considered to have 'female-typical' working-time arrangements; for example, music teachers (61\% part-time, 52\% telework) or translators (43\% part-time, $63 \%$ telework). In contrast, occupations with a high share of overtime and night work are considered to have 'maletypical' working-time arrangements; for example, managers (23\% overtime, $29 \%$ night work) or medical doctors ( $20 \%$ overtime, $50 \%$ night work). ${ }^{6}$

Measurements of 'male-typical' and 'female-typical' tasks on the occupational level were derived from the BIBB/BAuA Employment Survey of the Working Population on Qualification and Working Conditions in Germany 2006 (Hall and Tiemann, 2009) and were based on the question 'How often do you perform the following tasks at your work place - often, occasionally, or never?'. For each occupational category ${ }^{7}$ the weighted share of respondents was calculated who state that they often perform the tasks (1) 'computing/IT' (mean: 20\%) or (2) 'developing/constructing' (mean: 27\%), which can be labelled 'male-typical' work tasks and are found in occupations such as software developers (79\% computing/IT, 58\% developing/constructing) or electrical engineers $(57 \%$ computing/IT, 52\% developing/constructing). Furthermore, the share of respondents who often perform the tasks (3) 'teaching/educating' (mean: 30\%) or (4) 'healing/nursing/caring' (mean: 17\%) was computed, which can be labelled 'female-typical' work tasks and are found in occupations such as secondary school teachers ( $94 \%$ teaching/ educating, $28 \%$ healing/nursing/caring) or dentists (67\% teaching/educating, $91 \%$ healing/nursing/caring). ${ }^{8}$

To control for human capital on the occupational level, Becker's (1962) definition of general and specific human capital was applied. Based on the BIBB/BAuA Survey, the weighted mean of respondents was computed who state that they acquired the skills and knowledge for their current job mainly (1) through formal education, such as higher education or vocational education and training, which is labelled general human capital and (2) through work experience, which is labelled firm-specific human capital. ${ }^{9}$ In addition, the weighted mean of women in a given subject was calculated based on the HISAbsolventenpanel 2001 and matched to the respondents' fields of study to control for the gender composition of subjects. ${ }^{10}$

From the HIS-Absolventenpanel 2001, the following individual-level control variables were derived: the type of higher education degree to control for general human capital; a dummy variable on mandatory practical training phases as part of the degree course to control for the specificity of human capital; working in a large firm (> 500 employees), in the public sector, having a leadership position ${ }^{11}$ or being self-employed to control for a person's current job situation; working part-time $(\leqslant 30$ hours per week actual 
working hours) and working overtime often or very often ${ }^{12}$ to control for individual working time; number of months in employment (months in part-time employment were multiplied by 0.5 ) and in unemployment to control for the respondents' employment biographies since graduation; number of months in family-related employment breaks, the marital status (dummy variable for married) and whether respondents have children younger than 6 years to control for family formation.

A description of shares, means, and standard deviations of all variables is provided in the Online Appendix A. In the models, all independent continuous variables are mean centred. To check for multicollinearity, variance inflation factors (VIFs) were estimated (see Online Appendix B), which overall cannot be not considered problematic (see also Online Appendix C for a separate inclusion of the occupation-level predictors). Only the share of women and the share of part-time employees in an occupation have VIFs above 5, which points towards a collinear relationship (as was expected theoretically) and might lead to higher standard errors; yet estimation of regression coefficients is possible (Gujarati, 2003).

Methodologically, respondents' logged gross hourly wages about five years after graduation are estimated by using ordinary least squares (OLS) regressions with clustered standard errors on the occupational level, since the standard errors of individuals working in the same occupation are correlated with the explanatory variables on the occupational level. ${ }^{13}$ Additionally, Blinder-Oaxaca decompositions were estimated in order to quantify the effect of the different explanatory variables on the gender wage gap (Jann, 2008). Technically, the method is based on a so-called counterfactual model, explaining women's 'counterfactual wages' by inserting men's coefficients in the equation. ${ }^{14}$ It decomposes the raw gender wage into an 'explained' part, which is based on differences between men and women in observable characteristics (also called differences in endowments), and into an 'unexplained' part. This so-called residual gender wage gap is often used as a measure of discrimination, but also subsumes the effects of group differences in other unobserved predictors; for example, gender differences in successful wage negotiations (Stuhlmacher and Walters, 1999).

\section{Why do occupations dominated by women pay less? Empirical results}

Before analysing the gender wage gap by means of a multivariate analysis, the share of particular work tasks and working-time arrangements within female-dominated $(\geqslant 70 \%$ women) and male-dominated ( $\leqslant 30 \%$ women) occupations are compared. The left panel of Figure 1 shows that 'female-typical' work tasks like teaching/education and healing/ nursing/caring are found more often in occupations dominated by women, while 'maletypical tasks' like computing/IT and developing/construction are performed more often in occupations dominated by men. Regarding working-time arrangements (right panel), the graph indicates that part-time employment and telework is much more prominent in occupations dominated by women than in occupations dominated by men, while it is the other way around for overtime and night work, even though in the latter case to a much lower extent. 


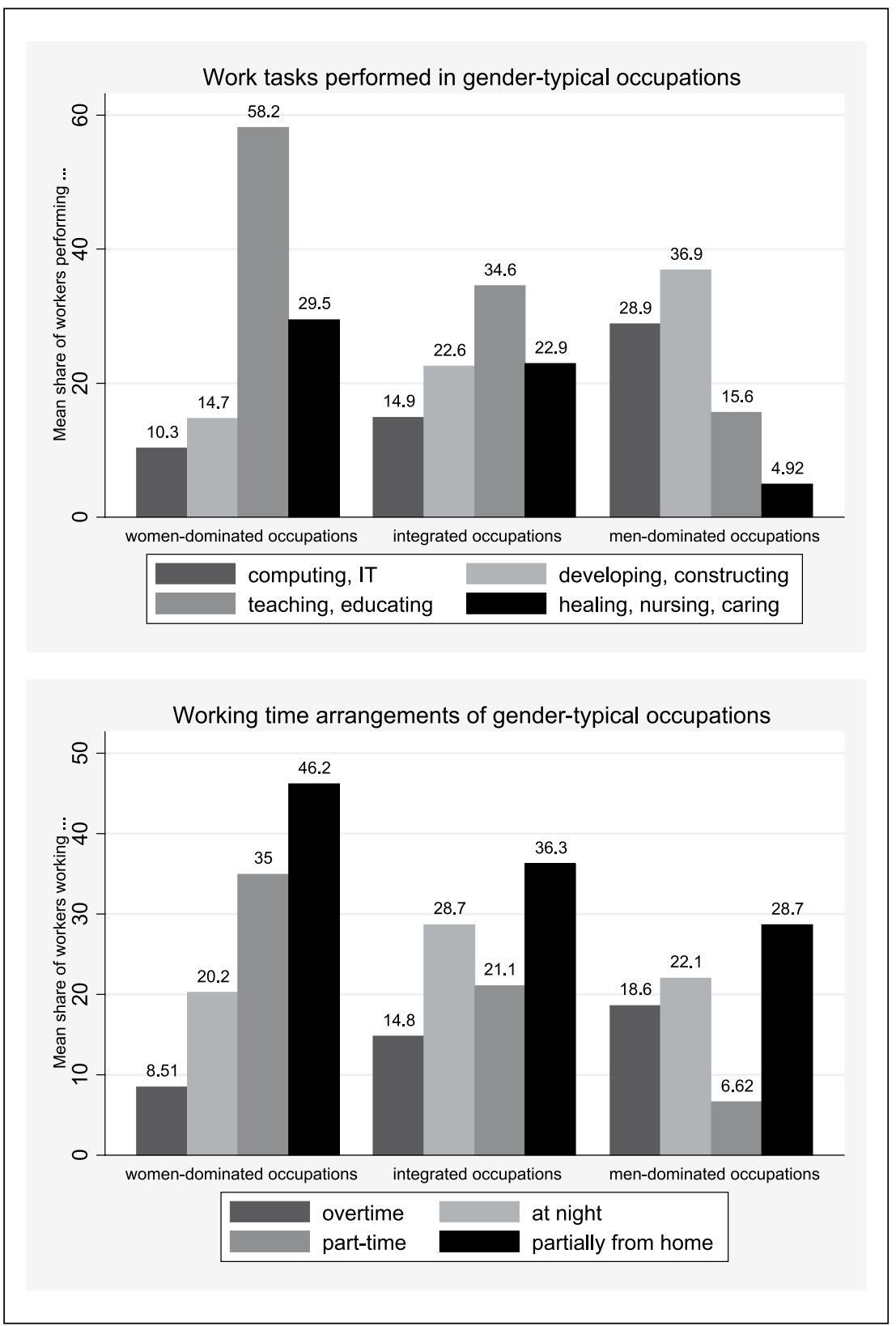

Figure I. Gender-typical occupations, work tasks and working-time arrangements. Sources: German Microcensus 2005, BIBB-BAuA 2006, authors' calculations.

In the following, OLS regressions with clustered standard errors on the occupational level are estimated to examine whether these gender-typical work tasks and working-time 
arrangements explain why occupations dominated by women pay less. Table 1 indicates that five years after graduation female higher education graduates earn 16.1 per cent less per hour than male graduates. Controlling for the share of women in an occupation (Model 1) decreases the female coefficient and has a negative effect on wages: if the share of women in an occupation is 10 per cent higher than the occupational average, the wages of persons working in this occupation are about four per cent lower. The question is whether occupations dominated by women pay less due to their female-typical work tasks or due to female-typical working-time arrangements.

The inclusion of work tasks (Model 2) further reduces the female coefficient, though only slightly. Occupations with a high share of 'computing/IT' tasks in particular pay higher wages, which would support the assumption that 'male-typical' work tasks are more highly valued. Yet, in contrast to the theoretical considerations, none of the 'femaletypical' work tasks seem to affect wages. In addition, and even more importantly, the coefficient for the share of women in an occupation remains unchanged. Only once individual-level variables are controlled for (Model 5), the share of teaching/educating performed in an occupation affects wages significantly. However, in contrast to our theoretical considerations, these 'female-typical' tasks now increase rather than reduce wages. This speaks against hypothesis 1 and adds to the inconclusive findings on this issue for Germany (e.g. Busch, 2013; Liebeskind, 2004).

The inclusion of working-time arrangements (Model 3) again only slightly reduces the female coefficient. However, the coefficient of the share of women in an occupation is hardly significant anymore $(p<0.10)$. This indicates that occupations dominated by women pay less due to their high levels of part-time employment and their low levels of overtime, which corresponds to Busch's (2013) findings for overtime. If the share of part-time employed is 10 per cent higher than the occupational average, the wages of persons working in this occupation are nine per cent lower, especially for women (Model 5 women). In contrast, a 10 per cent higher share of employees working overtime in an occupation results in a 10 per cent increase in wages, but only for men (Model 5 men). A high share of telework does not have a significant effect on individual wages, while night work slightly reduces wages for women only (Model 5 women).

Regarding the occupation- and subject-level control variables (Model 4), neither general nor firm-specific human capital seem to matter, while the share of women per subject has a significant negative effect on wages: subjects with a 10 per cent higher share of women above the average pay about two per cent lower wages, which supports previous research (Braakmann, 2013; Ochsenfeld, 2014). However, the subject effect is smaller than the occupation effect and more strongly affects men's wages than women's (Leuze and Strauß, 2014). After controlling for variables on the individual level (Model 5), all of the above-reported effects on the occupational level remain unchanged.

The results of the Oaxaca-Blinder decomposition (Model 5 decomposition) provide additional evidence on why occupations dominated by women pay less. In this regard, occupational working-time arrangements are particularly important: both the share of part-time employment and the share of working overtime in an occupation have large explanatory power; they account for 3.7 per cent and 2.5 per cent of the predicted gender wage gap, respectively. In line with the argument of gendered organizations (Acker, 


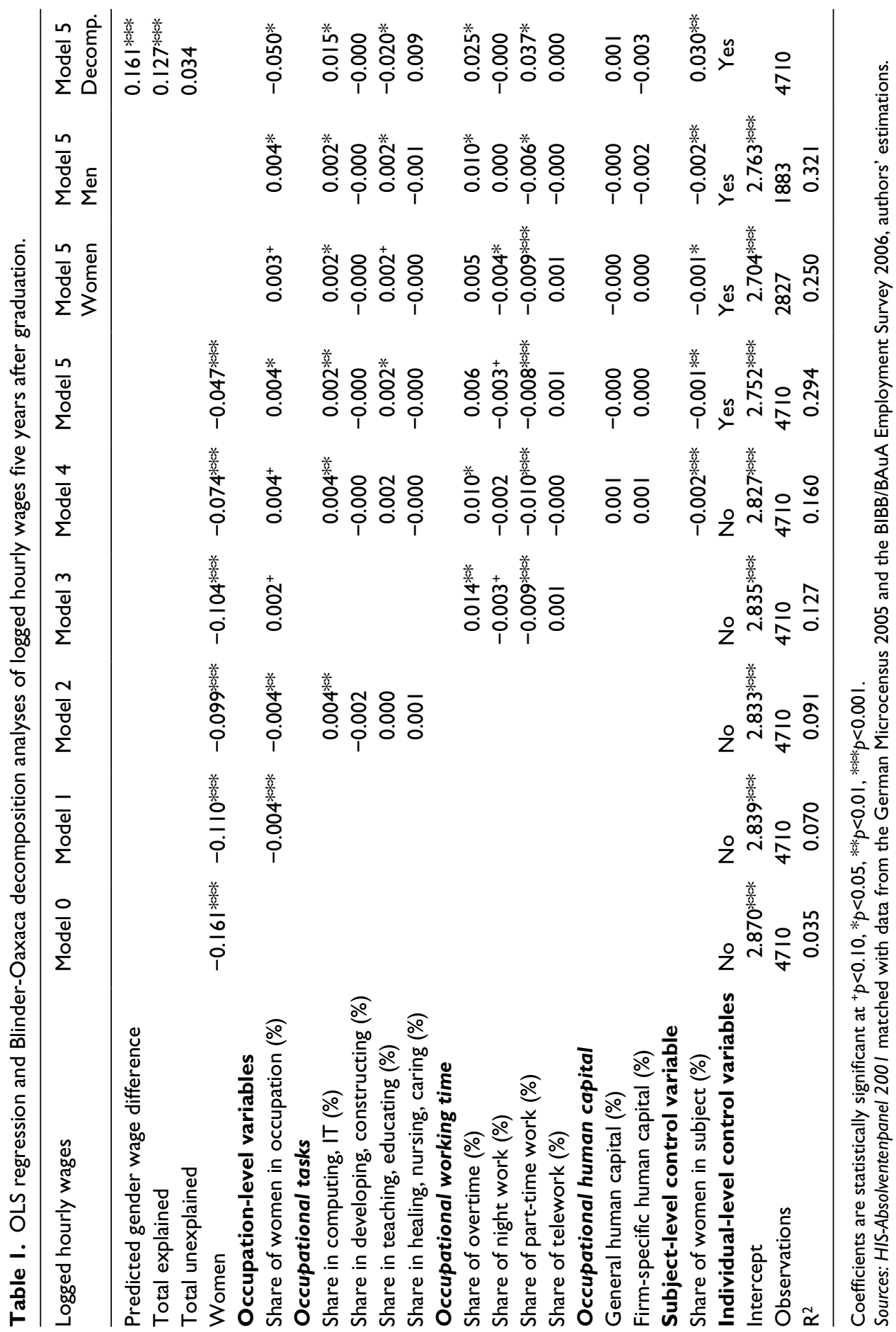


1990), these results support the hypothesis of a lower value of 'female-typical' and a higher value of 'male-typical' working-time arrangements on the occupational level.

In contrast, 'female-typical' and 'male-typical' work tasks at the occupational level explain a lower share of the gender wage gap; moreover, their effect for higher education graduates is in part contrary to what was expected theoretically. Working in an occupation with a high share of computing/IT explains about 1.5 per cent of the gender wage gap and thus supports the hypothesis that 'male-typical' activities have a higher societal value. Yet working in an occupation with a high share of teaching/educating activities has, once controlled for working time, a positive effect on wages, too, and is thus effective in reducing the gender wage gap $(-2.0 \%)$, which counters the idea that female-typical work tasks are generally devalued, at least not among the highly qualified. ${ }^{15}$

Of the predicted gender wage gap of 16.1 per cent, a total of 12.7 per cent can be explained by occupation- and individual-level variables, while the residual gender wage gap of 3.4 per cent is not significant any longer. However, even though our models demonstrate that occupational characteristics are important for understanding the gender wage gap, individual variables account for the largest share of this gap and are in line with previous findings (coefficients are provided in the Online Appendix D): women earn less due to their current employment situation (i.e. because they work more often in small firms and in the public sector and less often obtain leadership positions) (Petersen and Morgan, 1995; Triventi, 2013). However, women's wages would be even lower if they worked as much overtime as their male counterparts. This implies that our measure of overtime refers to unpaid overtime, which decreases hourly wages (Wolf, 2002) and not to paid overtime, which has been shown to increase the gender wage gap (Cha and Weeden, 2014). Finally, gender differences in employment histories during the first five years after graduation generate gender inequalities in wages, since women accumulate less work experience, but encounter unemployment more often (Ochsenfeld, 2014; Triventi, 2013). Yet family-related employment breaks, marriage and young children do not generate gender wage inequalities among higher education graduates during this early stage of their career.

\section{Discussion and conclusion}

Earlier research has shown that occupations with a high share of women are associated with lower wages and thus contribute to the gender wage gap. Several mechanisms have been discussed that are thought to explain why occupations dominated by women pay less. This article addresses two of them: the wage effects of 'gendertypical' work tasks and of 'gender-typical' working-time arrangements at the occupational level. The focus of this study is special insofar as it focuses exclusively on the wages of German higher education graduates five years after graduating in 2001 . This allows the examination of a group of respondents who are more homogeneous in terms of human capital, duration of labour market integration and phase of family formation when compared to the entire working population. In addition, they should hold similar stereotypes about 'male' or 'female' tasks of certain occupations, since people's understanding of 'maleness' or 'femaleness' differs between social strata (Buchmann and Kriesi, 2012). 
The empirical results show that the gender label of occupational work tasks has only limited explanatory relevance in the sample of higher education graduates. On the one hand, tasks like computing/IT increase wages. This is not surprising, given that these activities are performed very often in occupations related to science, technology, engineering and mathematics, which are dominated by men and pay high wages. On the other hand, and contrary to our theoretical expectations, occupations with a high share of 'female-typical' tasks (namely teaching/educating) pay higher wages, too. Since these work tasks are mainly performed by well-paid professionals, such as teachers or university professors, they are seemingly more valuable than if they were associated with occupations typically adopted by less qualified individuals, for example in the low-skill/ low-pay service sector.

Thus, for the selective group of higher education graduates the effects of work tasks to some extent even contradict earlier findings on the German working population as a whole (Busch, 2013; Liebeskind, 2004). Theoretically, these results speak against a general devaluation of 'female-typical' work tasks, since work tasks like 'caring activities' for high-skilled persons seem to differ substantially in terms of skill and remuneration from those activities for the broader, less-educated population beyond higher education graduates. This points in the direction of a polarization of labour market chances between high-skilled and low-skilled women, which has already been shown for the growing educational divide of mothers' employment in Germany (Konietzka and Kreyenfeld, 2010). Therefore, further research on the general working population should differentiate between various types of 'male' and 'female' work tasks (Buchmann and Kriesi, 2012) and analyse their effect on gender inequalities in the labour market for different social strata separately. By systematically integrating such a perspective of intersectionality, it will become possible to establish a clearer picture of which work tasks are culturally less valuable than others and for which group(s) of women.

Occupational working-time arrangements are more important for our understanding of why occupations dominated by women pay less. Since also highly qualified women work more often in occupations with a high share of part-time employment and less often in occupations with a high share of workers reporting overtime, they earn less than their male counterparts, which corresponds to findings for the general working population (Busch, 2013). According to Acker's (1990) theory of gendered organizations, 'male-typical' working-time arrangements in an occupation support the societal norm of an 'ideal worker' and therefore come along with higher wages. In contrast, 'female-typical' working-time arrangements are culturally less valuable since they are supposed to enable a better reconciliation of wage work and unpaid care work and therefore pay less.

Thus, our results suggest that the German 'modified male breadwinner model' (Trappe et al., 2015) is also supported by the structure of occupations, since those with 'maletypical' working-time arrangements enable the (mostly male) breadwinner to support a family, while those with female-typical working-time arrangements enable a (mostly female) carer to combine wage work with family responsibilities, yet at the expense of wage levels. Interestingly, the occupational basis for such a traditional division of wage work and care work is found even in such a selective sample of higher education graduates - a sub-group of the population that generally has more equal gender norms, but not 
necessarily a more equal division of labour between male and female partners when compared to lower educated couples (Usdansky, 2011).

However, does this mean that high-skilled women are disadvantaged because of their individual preferences for particular occupations and/or working-time arrangements, as the perspective of occupational sorting processes would suggest? From our point of view, such an individualist perspective neglects the context in which men and women 'choose' particular occupations. Individual preferences for particular working-time arrangements derive from gendered socialization processes, informal peer pressure and experiences in the education system and labour market as well as cultural norms regarding the division of wage work and care work (Crompton and Harris, 1998; Gash, 2008; Ginn et al., 1996). Women are still seen to be responsible for taking on the bulk of housework and childcare duties (Hook, 2010), even among the highly qualified (Usdansky, 2011). Thus, the 'choice' to work in an occupation with 'female-typical' working-time arrangements is not necessarily the result of women's personal preferences, but a consequence of the division of labour within couples and (the absence of) institutional support for combining wage work with care work (Nieuwenhuis et al., 2012; Steiber and Haas, 2012).

This is certainly the case in Germany, where public childcare is mainly available on a part-time basis for children aged three years and older (Budig et al., 2012). This care gap continues at school age because public schools also mostly operate on a half-day basis. Not least, this division of labour between married partners is also supported by the German taxation system which privileges couples with high income differences (Dingeldey, 2000). This leads many mothers, including those with higher education, to leave the labour market for considerable periods of time and re-enter in part-time jobs. Our findings thus support earlier qualitative research (Crompton and Lyonette, 2011; Herman and Lewis, 2012) suggesting that working-time arrangements are not only a matter of individual choice, but also an institutional characteristic linked to specific occupations, which are considered 'male' or 'female' and paid accordingly.

However, it is still an open question why occupations with a higher share of part-time workers pay lower wages and those with a higher share of overtime pay higher wages. Further research will have to establish in more detail how individual and collective wage setting processes take place in occupations with gendered working-time arrangements. In a comparative perspective it also remains to be seen how far these results can be generalized to countries with breadwinning models other than the German one. Most likely, this depends not only on the institutional support for mothers' employment, but also on national working-time norms and the institutional organization of part-time work.

\section{Acknowledgements}

The authors would like to thank the editor and the three anonymous reviewers for their helpful comments, which greatly improved this work. In addition, we would like to thank Maarten Buis, Thomas Hinz, Marcel Helbig and the participants of the research colloquium 'Quantitative and education sociology' at the Leibniz Universität Hannover for helpful comments on earlier versions of this article. We are also very grateful to Anna Erika Hägglund for helping us with setting up the HIS data. Data from the HIS-Absolventenpanel 2001 and the BIBB/BAuA Employment Survey of the Working Population on Qualification and Working Conditions in Germany 2006 were kindly 
provided by the GESIS Leibniz Institute for the Social Sciences, while data from the German Microcensus 2005 were kindly provided by the German Federal Statistical Office.

\section{Funding}

The authors received no financial support for the research, authorship and/or publication of this article.

\section{Notes}

1. The unadjusted gender wage gap refers to the raw wage differentials between men and women. After controlling for the so-called differences in endowment (e.g. differences regarding qualifications, work experience, or occupations), the adjusted gender wage gap can be calculated.

2. However, supporters of the sorting argument question the relevance of these devaluation processes (Ochsenfeld, 2014; Tam, 2000).

3. Even though the latest survey of the Absolventenpanel was started in 2009, only data for the graduation cohorts from 1997 and 2001 are available as scientific use files. The initial sample of 2001 graduates included 8103 individuals; five years later, panel attrition reduced the sample to 5426 individuals - which amounts to about 67 per cent of the initial sample size (Schramm and Beck, 2010). Men were slightly more likely (36\%) than women (31\%) to drop out of the survey (authors' estimations).

4. Estimating gross hourly wages (= gross monthly earnings / actual hours worked per month / 4.2 weeks per month) allows the examination of gender differences in wages net of working hours (Petersen, 1989).

5. One year after graduation, many graduates are still in practical training phases (e.g. medical doctors, lawyers, or teachers), which pay lower wages and thus might bias results. Five to six years after graduation, about 89 per cent of the respondents were employed (94\% men and $88 \%$ women), which is slightly higher than the 2005 employment rate of German tertiary graduates aged 25 to 34 years (85\%) (OECD, 2013: 92).

6. Also empirically, women more often work part-time and from home, while men more often work overtime and slightly more often at night (see Online Appendix A).

7. Due to a low number of cases for some categories, occupations with less than 10 respondents were merged with similar occupational categories.

8. Also empirically, women more often perform tasks like 'teaching/educating' and 'healing/ nursing/caring', while men more often perform tasks like 'IT/computing' and 'developing/ constructing' (see Online Appendix A). There are further tasks that are more often done by women (e.g. cooking/accommodating, buying/selling) and that have been shown to affect wages (e.g. Busch, 2013; Liebeskind, 2004). However, since these tasks are less often performed by high-skilled persons, they were not in the focus of our analysis. Furthermore, they do not change the reported results when included in the models (see Online Appendix E).

9. More direct measures of general or specific human capital were not available in the data set.

10. Due to the low number of cases for some categories, subjects with less than 20 respondents were merged with similar subjects.

11. Leadership positions account for the vertical segregation between men and women in the labour market. Measurement is based on the current employment position, which is independent of the occupation held, and includes positions in management, as freelancers, as entrepreneurs or in the upper civil service.

12. Since we do not have information on the contractual working hours, measurement of overtime is based on the respondents' answer to the question of whether they work overtime not at all (1) to very often (5). 
13. The application of multilevel random intercept linear regression models yielded similar results (see Online Appendix E).

14. There are other methodological approaches in the area of matching techniques which address this problem more directly (Frölich, 2007; Ñopo, 2008). Yet, in our case, the commonly used approach of the Blinder-Oaxaca decomposition is applicable since the male and female samples overlap to a very large degree.

15. A separate analysis for the public and the private sector (results not shown) reveals that the effects of part-time work and the work tasks are found mainly in the private sector, while the overtime surplus pertains to the public sector.

\section{References}

Acker J (1990) Hierarchies, jobs, bodies: a theory of gendered organizations. Gender \& Society 4(2): 139-58.

Becker GS (1962) Investment in human capital: a theoretical analysis. Journal of Political Economy 70(2): 9-49.

Becker GS (1985) Human capital, effort, and the sexual division of labor. Journal of Labor Economics 3(1): S33-58.

Bolton SC and Muzio D (2008) The paradoxical processes of feminization in the professions: the case of established, aspiring and semi-professions. Work, Employment and Society 22(2): 281-99.

Braakmann N (2013) What determines wage inequality among young German university graduates? Jahrbuecher fuer Nationaloekonomie und Statistik 233(2): 130-58.

Buchmann M and Kriesi I (2012) Geschlechtstypische Berufswahl: Begabungszuschreibungen, Aspirationen und Institutionen. Kölner Zeitschrift für Soziologie und Sozialpsychologie 52: 256-80.

Budig MJ and England P (2001) The wage penalty for motherhood. American Sociological Review 66(2): 204-25.

Budig MJ, Misra J and Boeckmann I (2012) The motherhood penalty in cross-national perspective: the importance of work-family policies and cultural attitudes. Social Politics: International Studies in Gender, State \& Society 19(2): 163-93.

Busch A (2013) Der Einfluss der beruflichen Geschlechtersegregation auf den 'Gender Pay Gap'. Kölner Zeitschrift für Soziologie und Sozialpsychologie 65(2): 301-38.

Cha Y and Weeden KA (2014) Overwork and the slow convergence in the gender gap in wages. American Sociological Review 79(3): 457-84.

Charles M and Bradley K (2009) Indulging our gendered selves? Sex segregation by field of study in 44 countries. American Journal of Sociology 114(4): 924-76.

Connell RW (1987) Gender and Power. Sydney: Allen and Unwin.

Crompton R and Harris F (1998) Explaining women's employment patterns: 'orientations to work' revisited. British Journal of Sociology 49(1): 118-36.

Crompton R and Lyonette C (2011) Women's career success and work-life adaptations in the accountancy and medical professions in Britain. Gender, Work and Organization 18(2): 231-54.

Dingeldey I (2000) Einkommenssteuersysteme und familiale Erwerbsmuster im europäischen Vergleich. In: Dingeldey I (ed.) Erwerbstätigkeit und Familie in Steuer- und Sozialversicherungssystemen. Opladen: Leske+Budrich, 11-47.

England P (1992) Comparable Worth: Theories and Evidence. New York: Aldine de Gruyter.

England P and Li S (2006) Desegregation stalled: the changing gender composition of college majors, 1971-2002. Gender \& Society 20(5): 657-77. 
England P, Budig M and Folbre N (2002) Wages of virtue: the relative pay of care work. Social Problems 49(4): 455-73.

England P, Farkas G, Kilbourne BS and Dou T (1988) Explaining occupational sex segregation and wages: findings from a model with fixed effects. American Sociological Review 53(4): $544-58$.

England P, Hermsen JM and Cotter DA (2000) The devaluation of women's work: a comment on Tam. American Journal of Sociology 105(6): 1741-51.

Filer RK (1985) Male-female wage differences: the importance of compensating differentials. Industrial and Labor Relations Review 38(3): 426-37.

Frölich M (2007) Parametric and nonparametric regression in the presence of endogenous control variables. International Statistical Review 76(2): 214-27.

Gangl M and Ziefle A (2009) Motherhood, labor force behavior, and women's careers: an empirical assessment of the wage penalty for motherhood in Britain, Germany, and the United States. Demography 46(2): 341-69.

Gash V (2008) Constraints or preferences? Identifying answers from part-time workers' transitions in Denmark, France and the United Kingdom. Work, Employment and Society 22(4): 655-74.

Ginn J, Arber S, Brannen J, Dale A, Dex S, Elias P, Moss P, Pahl J, Roberts C and Rubery J (1996) Feminist fallacies: a reply to Hakim on women's employment and whose myths are they anyway: a comment. British Journal of Sociology 47: 167-77.

Gottschall K and Schröder T (2013) "Familienlohn" - zur Entwicklung einer wirkmächtigen Normierung geschlechtsspezifischer Arbeitsteilung. WSI Mitteilungen 66: 161-70.

Grönlund A and Magnusson C (2013) Devaluation, crowding or skill specificity? Exploring the mechanisms behind the lower wages in female professions. Social Science Research 42(4): 1006-17.

Gujarati DN (2003) Basic Econometrics, 4th Edition. Boston, MA: McGraw-Hill.

Hakim C (1996) Key Issues in Women's Work: Female Heterogeneity and the Polarisation of Women's Employment. London and Atlantic Highlands, NJ: Athlone Press.

Hall A and Tiemann M (2009) BIBB/BAuA employment survey of the working population on qualification and working conditions in Germany 2006, suf_1.0. In: Research Data Center at BIBB (ed.) GESIS Cologne (Data Access). Bonn: Federal Institute for Vocational Education and Training.

Helbig M and Leuze K (2012) Ich will Feuerwehrmann werden! Wie Eltern, individuelle Leistungen und schulische Fördermaßnahmen geschlechts(un-)typische Berufsaspirationen prägen. KZfSS Kölner Zeitschrift für Soziologie und Sozialpsychologie 64(1): 91-122.

Herman C and Lewis S (2012) Entitled to a sustainable career? Motherhood in science, engineering, and technology. Journal of Social Issues 68(4): 767-89.

Hook JL (2010) Gender inequality in the welfare state: sex segregation in housework. 1965-2003. American Journal of Sociology 115(5): 1480-523.

Jann B (2008) The Blinder-Oaxaca decomposition for linear regression models. The Stata Journal 8(4): 453-79.

Kilbourne BS, Farkas G, Beron K, Weir D and England P (1994) Returns to skill, compensating differentials, and gender bias: effects of occupational characteristics on the wages of white women and men. American Journal of Sociology 100(3): 689-719.

Konietzka D and Kreyenfeld M (2010) The growing educational divide in mothers' employment: an investigation based on the German micro-censuses 1976-2004. Work, Employment and Society 24: 260-78.

Lechert Y and Schimpl-Neimanns B (2007) Mikrozensus Scientific Use File 2005: Dokumentation und Datenaufbereitung. ZUMA-Methodenbericht 2007/08. Mannheim: ZUMA. 
Leuze K and Strauß S (2009) Lohnungleichheiten zwischen Akademikerinnen und Akademikern: der Einfluss von fachlicher Spezialisierung, frauendominerten Fächern und beruflicher Segregation. Zeitschrift für Soziologie 38(4): 262-81.

Leuze K and Strauß S (2014) Female-typical subjects and their effect on wage inequalities among higher education graduates in Germany. European Societies 16(2): 275-98.

Liebeskind U (2004) Arbeitsmarktsegregation und Einkommen - vom Wert "weiblicher" Arbeit. Kölner Zeitschrift für Soziologie und Sozialpsychologie 56: 630-52.

McGrath S and DeFilippis J (2009) Social reproduction as unregulated work. Work, Employment and Society 23(1): 66-83.

Nieuwenhuis R, Need A and Van Der Kolk H (2012) Institutional and demographic explanations of women's employment in 18 OECD countries, 1975-1999. Journal of Marriage and Family 74(3): 614-30.

Ñopo H (2008) Matching as a tool to decompose wage gaps. The Review of Economics and Statistics 90(2): 290-9.

Ochsenfeld F (2014) Why do women's fields of study pay less? A test of devaluation, human capital, and gender role theory. European Sociological Review 30(4): 536-48.

OECD (2013) Education at a Glance 2013: OECD Indicators. Paris: OECD Publishing.

Perales F (2013) Occupational sex-segregation, specialized human capital and wages: evidence from Britain. Work, Employment and Society 27(4): 600-20.

Petersen T (1989) The earnings function in sociological studies of earnings inequality: functional form and hours worked. Research in Social Stratification and Mobility 8: 221-30.

Petersen T and Morgan LA (1995) Separate and unequal: occupation-establishment sex segregation and the gender wage gap. American Journal of Sociology 101(2): 329-65.

Polachek SW (1981) Occupational self-selection: a human capital approach to sex differences in occupational structure. The Review of Economics and Statistics 63(1): 60-9.

Ridgeway CL (1997) Interaction and the conservation of gender inequality: considering employment. American Sociological Review 62(2): 218-35.

Schramm M and Beck S (2010) Dokumentation des Scientific Use Files "HIS Absolventenpanel 2001'. Hannover: Hochschul-Informations-System.

Stadelmann-Steffen I (2008) Women, labour, and public policy: female labour market integration in OECD countries. A comparative perspective. Journal of Social Policy 37(3): 383-408.

Steiber N and Haas B (2012) Advances in explaining women's employment patterns. SocioEconomic Review 10(2): 343-67.

Stuhlmacher AF and Walters AE (1999) Gender differences in negotiation outcome: a metaanalysis. Personnel Psychology 52: 653-77.

Tam T (2000) Occupational wage inequality and devaluation: a cautionary tale of measurement error. American Journal of Sociology 105(6): 1752-60.

Tomaskovic-Devey D and Skaggs S (2002) Sex segregation, labor process organization, and gender earnings inequality. American Journal of Sociology 108(1): 102-28.

Trappe H, Pollmann-Schult M and Schmitt C (2015) The rise and decline of the male breadwinner model: institutional underpinnings and future expectations. European Sociological Review 31(2): $230-42$.

Triventi M (2013) The gender wage gap and its institutional context: a comparative analysis of European graduates. Work, Employment and Society 27(4): 563-80.

Usdansky ML (2011) The gender-equality paradox: class and incongruity between work-family attitudes and behaviors. Journal of Family Theory \& Review 3: 163-78.

Wolf E (2002) Lower wage rates for fewer hours? A simultaneous wage-hours model for Germany. Labour Economics 9(5): 643-63. 
Ziegler A (2005) Erwerbseinkommen. In: Bothfeld S, Klammer U, Klenner C, Leiber S, Thiel A and Ziegler A (eds) WSI-FrauenDatenReport 2005. Handbuch zur wirtschaftlichen und sozialen Situation von Frauen. Berlin: Edition Sigma, 241-306.

Kathrin Leuze is Professor of Education Sociology at the Leibniz Universität Hannover, Germany. Her research interests include issues of life course sociology with a specific focus on higher education, labour market returns, occupational sex segregation, gender inequalities and cross-national comparisons. She currently directs the research project 'Occupational sex segregation and its consequences for the (re-)production of gender inequalities in the German labour market'.

Susanne Strauß is Professor of Sociology with a special focus on gender studies at the University of Konstanz, Germany. Her research interests include gender inequalities on the labour market and in the educational system as well as country-comparisons regarding the division of labour between couples regarding paid and unpaid work, such as caring and volunteering.

Date submitted October 2013

Date accepted October 2015 